\title{
Analysis on the Influence of Emotional Intelligence on the Performance of Managers and Organisational Effectiveness in the it Industry
}

\author{
Vani. M, H Sankaran, S. Praveen Kumar
}

\begin{abstract}
Emotional Intelligence is understood as an essential component to succeed in professional life and to lead a balanced social life. The role of managers is imperative especially in the IT industry. This study was administered to analyze the level of influence emotional intelligence can have on the performance of Managers in the IT Industry. Questionnaire method was adopted to gather the data from Managers working in the Information Technology Industry. The tool deployed for this study was SPSS to check the research hypothesis. The results of the present analysis show that there was a positive influence of EI on the performance of the managers which in turn contributes to the organizational effectiveness. Further, the output of the ANOVA test analysis indicates that there exists a notable difference in the influence of emotional intelligence on the performance of managers which in turn enhances the organization's effectiveness
\end{abstract}

Key Words: Emotional intelligence, Managerial Performance, Organizational effectiveness

\section{INTRODUCTION}

The term emotional intelligence was first introduced by Peter Salovey and John D. Mayer, Emotional intelligence essentially refers to an individual's social and self competence, in other words the extent to which their self and social awareness take them forward in their work space and personal life defines the point of the individual's scale of success. According to Daniel Goleman, a psychologist, who popularized the term Emotional Intelligence, it is described as "a person's ability to manage his feelings so that those feelings are expressed appropriately and effectively". As addressed by Dr. Goleman, emotional intelligence is the best predictor of success in workplace.

Robert K. Cooper has defined EI as "the ability to sense, understand, and effectively apply the power and acumen of emotions as a source of human energy, information, connection, and influence."

Revised Manuscript Received on July 22, 2019.

Vani M, MBA, Bharath Institute of Higher Education and Research, Tambaram, India.

H Sankaran , MBA, Meenakshi College of Management Studies, Kodambakkam, India.

S Praveen Kumar, MBA, Bharath Institute of Higher Education and Research, Tambaram, India

\section{EMOTIONAL INTELLIGENCE AND ITS DIMENSIONS}

As described by Dr. Goleman, there are five main Dimension of emotional intelligence.

\section{A. Self-Awareness}

A Clear understanding of self acts as a great strength for an Individual to access his own Strengths and Weaknesses, this is a firm indicator of emotional intelligence. Managers with this quality are receptive, work constructively on critical criticism and are focused towards Learning.

\section{B. Self-Regulation}

Regulating and balancing one's own emotions helps managers become more resilient and stay composed when expressing their emotions.

\section{Motivation}

Research has shown that Managers with High EI are Selfmotivated, strong and are steered by their inner strength to achieve rather than getting influenced by outside forces.

\section{Empathy}

A Manager should be capable of connecting with his team and peers at their emotional level, this can help managers understand his team's requirements and genuinely respond to their concerns.

\section{E. Social Skills}

Managers who are emotionally intelligent can easily build the trust with his team and can quickly gain the respect of his peers.

\section{EMOTIONAL INTELLIGENCE AND MANAGERIAL PERFORMANCE}

According to research carried out by Salovey and Mayer, Managers with emotional intelligence are able to

- Understand their own emotions which may be either positive or negative.

- Understand the emotions of peers which includes both positive and negative.

- Effectively manage their emotions to seek their goal and

- They induce the positive emotion into their team for the greater success.

In all EI has become the 
Analysis on the Influence of Emotional Intelligence on the Performance of Managers and Organisational Effectiveness in the it Industry

strongest prerequisite and performance predictor. Research conducted by Career builder has identified that Managers with high EQ stay composed under pressure, resolve conflicts better and maintain a better social relationship. Managers within the organization set the tone, if the Managers are unable to exhibit the EI traits it may lead to lower employee engagement and a higher rate of turnover which may have a brunt on their work.

\section{IMPACT OF EI ON ORGANIZATIONAL EFFECTIVENESS}

There are huge challenges that are faced by all IT firms lately, the need for adapting to change, updating Technologies, the need to update unique skill sets in specific domains in various software programs, the acquisition of appropriate talent, attrition, work life balance etc has thrown a challenge to all the departments in the IT industry, testing the efficiency of output. Keeping the technical factors aside the Leaders in the Management together with HR department have realized the essence of incorporating EI as a tool towards success. Every stage the term EI seems to be significant be it Recruitment of the correct talent, or during training and development or during the project implementation stage Emotional intelligence seems to have an impact on the overall operations of the organization. To be effective in assisting their organization control the change, leaders first required to be alert and control their own feelings of anxiety and ambiguity (Bunker, 1997). Then they need to be alert of the emotional feedbacks of other organizational members and act to assist people to handle with those reactions. At the same time with the technique of coping effectively with huge change, other members of the organization need to be dynamically involved in observing and handling their emotional reactions [7].

\section{OBJECTIVE OF STUDY}

The intent of this study is to understand the influence of emotional intelligence on the performance of Managers in the IT Industry and if their performance affect the overall effectiveness of the organization.

\section{RESEARCH METHODOLOGY}

This section includes the following research model. The below models contains the observed endogenous variables and unobserved exogenous variables (Managerial Performance and organizational effectiveness), and the proposed relationship between them.

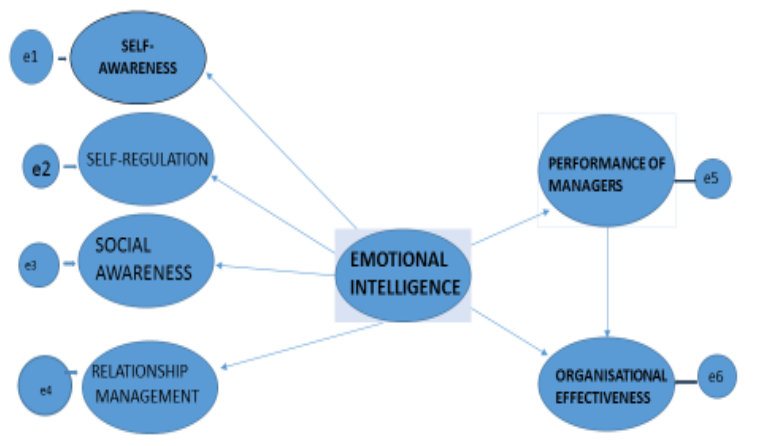

Figure1. Research Model

\section{A. Research Hypothesis}

To analyze the research model, to study the influence of EI on performance of Managers and organizational efficiency, the hypothesis was framed

Hypothesis 1: Higher level of Emotional Intelligence among managers will lead to better performance

\section{DATA ANALYSIS AND RESULTS}

The populations considered for the study were people working as managers in various IT organizations in a particular City. The questionnaires were circulated among 300 IT managers of which 250 responded to the questionnaires completely. The questionnaire had questions focusing on the demographic details of the managers and the others focused to measure the independent and dependent variables.

To find the effect of EI on Managerial Performance and organizational effectiveness, in which the related variables have been calculated using 5-points Likert scale that fluctuates between strongly disagree $=1$ and strongly agree $=$ 5 ;

\section{ANALYSIS ON SAMPLE}

Percentage analysis is one of the statistical measures used to describe the characteristics of the sample or population in totality.

Table 1.0 Frequency Distribution of Gender of Managers

\begin{tabular}{|l|c|c|}
\hline $\begin{array}{c}\text { Managers in } \\
\text { IT Industry }\end{array}$ & Frequency & Percent \\
\hline Male & 147 & 58.8 \\
\hline Female & 103 & 41.2 \\
\hline Total & 250 & 100.0 \\
\hline
\end{tabular}

From the above table, $58.8 \%$ of the employees considered for this study are Male and $41.2 \%$ of the employees are Females.

Table 1.1 Frequency Distribution of Age group of the Managers in years in IT Industry

\begin{tabular}{|l|c|c|}
\hline $\begin{array}{c}\text { Age group of the } \\
\text { Managers in years in } \\
\text { IT Industry }\end{array}$ & Frequency & Percent \\
\hline $25-35$ & 148 & 59.2 \\
\hline $36-45$ & 102 & 40.8 \\
\hline Total & 250 & 100.0 \\
\hline
\end{tabular}

From the above table, $59.2 \%$ of Managers fall under the age group of $25-35$ and $40.8 \%$ of the Managers fall under the age group of $36-45,26.5 \%$.

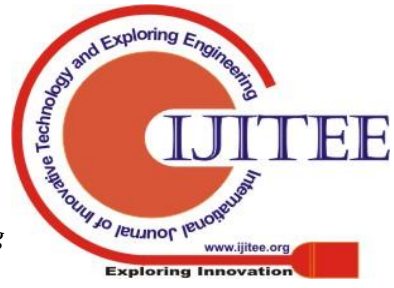


Table 1.2 Analysis of Emotional Intelligence on Performance of Managers in IT Industry

\begin{tabular}{|c|c|c|c|c|c|c|}
\hline \begin{tabular}{|c} 
Factors \\
Influencing the \\
Performance
\end{tabular} & & $\begin{array}{l}\text { Sum of } \\
\text { Squares }\end{array}$ & df & $\begin{array}{l}\text { Mean } \\
\text { Square }\end{array}$ & $\mathbf{F}$ & Sig. \\
\hline \multirow{3}{*}{$\begin{array}{l}\text { Overall } \\
\text { Emotional } \\
\text { Intelligence }\end{array}$} & \begin{tabular}{|l} 
Between \\
Groups
\end{tabular} & 161.288 & 3 & 3.763 & 6.059 & .000 \\
\hline & \begin{tabular}{|l} 
Within \\
Groups \\
\end{tabular} & 554.998 & 226 & 8.874 & & \\
\hline & Total & 716.286 & 229 & & & \\
\hline \multirow{3}{*}{$\begin{array}{l}\text { Organizational } \\
\text { Effectiveness }\end{array}$} & $\begin{array}{l}\text { Between } \\
\text { Groups }\end{array}$ & 22.288 & 3 & 4.429 & 6.038 & .000 \\
\hline & \begin{tabular}{|l|} 
Within \\
Groups \\
\end{tabular} & 464.24 & 226 & 7.427 & & \\
\hline & Total & 489.818 & 229 & & & \\
\hline \multirow{3}{*}{$\begin{array}{l}\text { Managerial } \\
\text { Performance }\end{array}$} & \begin{tabular}{|l} 
Between \\
Groups \\
\end{tabular} & 123.650 & 3 & 4.217 & 6.437 & .000 \\
\hline & \begin{tabular}{|l|} 
Within \\
Groups
\end{tabular} & 494.935 & 226 & 3.570 & & \\
\hline & Total & 618.586 & 229 & & & \\
\hline
\end{tabular}

From the above table it is evident that Emotional Intelligence has a significant influence on the performance of the Managers and the overall Effectiveness of the Organization.

The above table shows that the mean values for Managerial performance and Emotional intelligence are highest ( $\mathrm{F}$ value 6.437 ,P value $<0.001 * *$ ) and ( $\mathrm{F}$ value $6.059, \mathrm{P}$ value $<0.001 * *)$ respectively.

\section{CONCLUSION}

Behavioral Psychology indicates that people behave differently in different situations. Managers and employees if trained to handle Emotions, they can balance work, exhibit better team work and reduce work conflicts, better EI managers can act as counselors for their team to bring out the best output which in turn increases their job satisfaction and the overall organizational effectiveness. Better EI in Managers will lead to better productivity, innovation, better relationship management, robust in handling Finances and contributing to the overall organisational effectiveness.

\section{RECOMMENDATION}

The Management of IT and ITES companies should invest in training their Managers on Emotional Intelligence especially in the areas of Relationship management, Self-Awareness and Social Awareness to groom them as better leaders in an urbanized environment. If EI Training modules are introduced on a periodical basis, these organizations can for sure see a better result that contributes to the positive work culture within an organization.
2. BahdorGanjehKhosra , MahmoudManafi, "The Impact of Emotional Intelligence towards the Effectiveness of Delegation: A Study in Banking Industry in Malaysia"

3. Bano Fakhra Batool," Emotional Intelligence and Effective Leadership", Journal of Business Studies Quarterly, Volume 4, Number 3, 2013.

4. Dr. Manoj Kumar Choudhary," Correlation: Leadership Skill and Emotional Intelligence", American International Journal of Research in Humanities, Arts and Social Sciences, pp. 138-139, 2014.

5. BhawnaChahar, Dr. Surekha Rana," Emotional Intelligence and Managerial Effectiveness," Volume-4, Issue-2, ISSN-2250-0669, July 2014.

6. Dr. Uma Selvi and Jane Joshua, A., "Emotional Intelligence and Managerial Effectiveness of Managerial Executives,"- Cauvery Research Journal, Volume 4, Issue 1 \& 2, Jul. 2010 - Jan. 2011

7. Dr. Chandra Mohan, A and Prasad, B. V. S, "Emotional Intelligence and Self Motivational Factors for Managerial Effectiveness in the Corporate World", NATIONAL MONTHLY REFEREED JOURNAL OF RESEARCH IN COMMERCE \& MANAGEMENT, VOLUME NO.1, ISSUE NO.11.

8. Hassan Jorfi, "The impact of emotional intelligence on communication effectiveness: Focus on strategic alignment", African Journal of Marketing Management, Vol. 6(5), pp. 82-87, October, 2014

9. M. Suvarchala Rani, "Emotional Intelligence - A Model for Effective Leadership, Competency and Career Growth", Indian Journal of Science and Technology, Vol 8 (S4), 240-246, February 2015.

10. Vladimir, "Project Managers Emotional Intelligence - A Ticket to Success", Journal in Procedia - Social and Behavioral Sciences, 74 $274-284,2013$

\section{AUTHORS PROFILE}

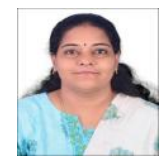

Vani. M, Research Scholar, Bharath Institute of Higher Education and Research, India

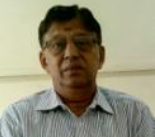

Dr. Dr.H. Sankaran, Principal, Meenakshi College of Management studies, India

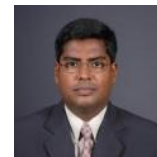

S. Praveen Kumar Director - MBA at Bharath Institute of Higher Education and Research, India

\section{REFERENCES}

1. Md. Sahidur Rahmana, Md. Aftab Uddina, and Mostafizur Rahman, "Role of emotional intelligence in managerial effectiveness: An empirical study", 2016. 